\title{
Dr. Ian Boustead
}

\author{
James Fava • Frank Consoli
}

Received: 18 April 2013 /Accepted: 25 April 2013 /Published online: 9 May 2013

(C) Springer-Verlag Berlin Heidelberg 2013

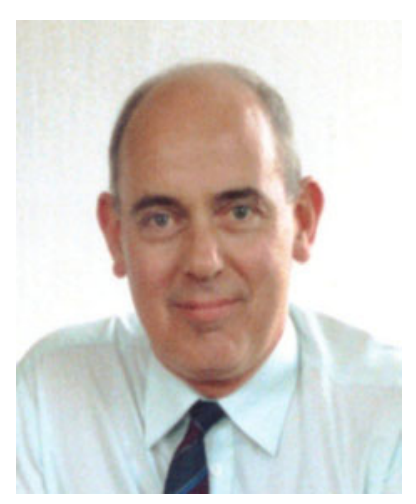

The worldwide life cycle assessment (LCA) community lost one of its founding members with the passing of Dr. Ian Boustead in 2011. Dr. Boustead was a rare individual-he was a dedicated and passionate devotee of the scientific method and was one of life's true optimists.

Most of the LCA community was first introduced to Ian during the first Society of Environmental Toxicology and Chemistry (SETAC) Pellston workshop conference in 1990. Seated in the back of the room, he frequently muttered as speakers presented various aspects of system methodology - 'credits - systems don't give a damn about credits'...... and so his relationship with the LCA community began.

Born in the North East of England, Ian achieved a BSc in Physics at the University of Birmingham in 1960. After 4 years teaching mathematics, he joined the Royal College of Military

\section{J. Fava $(\bowtie)$}

PE International, 626 Meadow Drive,

West Chester, PA 19380-6235, USA

e-mail: J.Fava@pe-international.com

\section{F. Consoli}

Competitive Innovation, LLC, Rose Tree Corporate Center 1,

Suite 105, 1400 N. Providence Road,

Media, PA 19063-2052, USA

e-mail: fjconsoli@competitiveinnovation.com
Science at Shrivenham, gaining MSc and $\mathrm{PhD}$ degrees. In 1972, he joined a fledgling Open University (OU) as a Staff Tutor in the Technology Faculty. During this time, his interest in energy reporting developed and he formed a business partnership with Dr. Gerry Hancock: the pair wrote and published the 'Handbook of Industrial Energy Analysis' in 1979. Two more books followed: further work led to Ian being engaged by the UK government to produce the Industry Council on Packaging in the Environment report on packaging materials (published 1993).

Ian was a major contributor to LCA methodology development and practice both through his groundbreaking early work and later through his participation in the series of SETAC LCA conferences; he was also a leader on the SETAC LCA Advisory Committee throughout the method's 'formulative' years, and through his involvement on the ISO LCA committee that established the 14040 LCA Standards that all LCA studies now follow. Throughout these engagements, Ian staunchly defended scientific principles and methods and his prodigious writing skill helped to establish the methodology we know today.

Ian left the OU in 1994, forming and managing Boustead Consulting, Ltd. The institute recognised his work by awarding him its prestigious Melchett Medal in 1997.

In one of his last published LCA Journal articles, Ian so aptly summed up his relationship to LCA: 'When I first became involved in this subject, I never expected that I would still be in it 25 years later. As the subject has developed during this period, there have always been more questions raised than were answered and this has kept the subject alive and sparkling. I am always amazed at the speed with which recent entrants to the field have become experts; but then, maybe I am just getting old!'

Ian was very well-read and had a rich sense of humour. He will forever be remembered by LCA enthusiasts for his knack for telling colourful stories to demonstrate LCArelated concepts as well as his significant contributions to the field we all love. 